UDC 658.562.012.7

\author{
(C) M. Zenkin, Doctor of Technical Sciences, Professor, \\ Igor Sikorsky KPI, Kyiv, Ukraine
}

\title{
PRINT QUALITY CONTROL USING STATISTICAL METHODS
}

\begin{abstract}
An analysis of various studies was performed, which allowed to identify consumer requirements for the final product. The principles and practical methods of General Quality Management TQM are described. It is noted that strict control, which is designed to ensure maximum quality for print production, is not limited to one calibration test run - the printing results must be checked constantly.
\end{abstract}

Keywords: quality management; statistical methods; offset printing; estimation accuracy; quality control.

\section{Introduction}

The quality of products (services) is crucial in assessing the performance of each enterprise or organization. The production of efficient and high-quality products allows the company to get more additional profit, to ensure rapid production development. In order to achieve high-quality printing, it is necessary to combine the creative potential and practical experience of many specialists from different departments. An important role in solving the problem of quality improvement is played by consumers, who dictate their requirements, requests to producers of goods and services and evaluate the results of the organization.

The task of statistical methods is to ensure the production of products that meet the requirements of consumers at the lowest cost. For this purpose the analysis and research of operations at the en- terprise is carried out. Due to the use of statistical methods of product quality control it is possible to achieve quality improvement.

In addition, statistical methods of quality control help to more expediently and rationally build the technological process, carrying out control at its various stages.

\section{Research methods}

\section{and problem statement}

Various theoretical principles and practical methods include General TQM Quality Management. Quality is achieved by involving all staff in activities to improve the work. The goal of quality improvement is to meet the needs of consumers and benefit all stakeholders and society as a whole.

It is known that statistical analysis of product quality is the study of conditions and factors that affect the quality of the object under analysis [1-3]. Analysis of various studies, including the use of the 
method of structuring the quality function, revealed consumer requirements [4]. The most important requirements of consumers are the components of the information function of multicolor products, the provision of which is achieved by meeting the quality requirements of the following indicators: homogeneity of the printed substrate, optical density, color gamut, color continuity, etc. Production of quality products at minimal cost the main goal of every company.

Printing standard - determining the optimal reference tolerances and conditions for a particular technology.

Work according to standardized methods is not limited to obtaining the relevant requirements of the results standard. Strict control, which is designed to ensure maximum quality for print production, is not limited to one calibration test run - print results must be checked constantly. Therefore, the issue of quality control is becoming more relevant every day [5].

\section{Results and discussion}

Analysis of the standard ДСТУ ISO 12647-2:2008 (based on ISO
12647-2: 2004) [6] showed that it presents the following standardized indicators:

- five reference paper types in CIELAB coordinates;

- CIELAB coordinates for base inks (CMYK) and tolerances for three types of paper;

- secondary coordinates (RGB) for three types of paper;

- reference tonal values and tolerances for three types of paper, determination of spreading in midtones;

- CMYK values for gray balance scales;

- Variability tolerances for base inks and printing when printing circulation.

ISO 12647-2: 2004 does not contain:

- optimal density values for three types of paper;

- CIELAB value for gray balance;

- paper parameters of specific manufacturers;

- color parameters of specific manufacturers;

- parameters of plates of specific manufacturers;

- specific additives and other auxiliary materials for printing.

Table 1

The value of optical density according to ДСТУ ISO 12647-2:2008

\begin{tabular}{|c|c|c|c|}
\hline \multirow{2}{*}{ Colors } & \multicolumn{3}{|c|}{ Optical density values and tolerances } \\
\cline { 2 - 4 } & $\begin{array}{c}\text { Paper } \\
\text { coated glossy }\end{array}$ & $\begin{array}{c}\text { Paper } \\
\text { coated matte }\end{array}$ & $\begin{array}{c}\text { Paper } \\
\text { Offset }\end{array}$ \\
\hline Cyan & $1,55 \pm 0,1$ & $1,45 \pm 0,1$ & $1,00 \pm 0,1$ \\
\hline Magenta & $1,50 \pm 0,1$ & $1,40 \pm 0,1$ & $0,95 \pm 0,1$ \\
\hline Yellow & $1,45 \pm 0,1$ & $1,25 \pm 0,1$ & $0,95 \pm 0,1$ \\
\hline Black & $1,85 \pm 0,15$ & $1,75 \pm 0,15$ & $1,25 \pm 0,15$ \\
\hline
\end{tabular}


The standard defines the measurable results to be achieved (tab. 1), but does not provide methods and recommendations for achieving them.

Modern methods of quality management control the quality of the product at all stages of its life cycle. The main purpose of the quality control system is to reduce the number of defects and avoid it completely. To do this, during the control, various deviations from the established norms are analyzed [7, 8].

Statistical methods of quality control are an important condition for the rational construction of the technological process. These methods are used at all stages of the product life cycle.

One of the leading places in the management and control system is the construction of control charts. Control charts are a plot of time series with the specified upper and lower limits. Three lines are

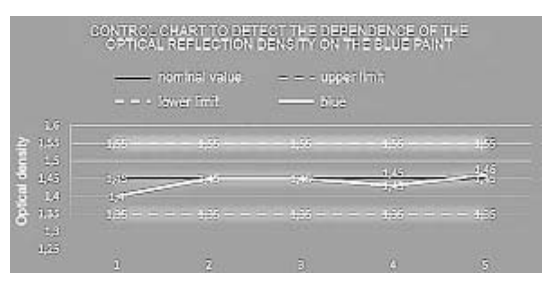

a

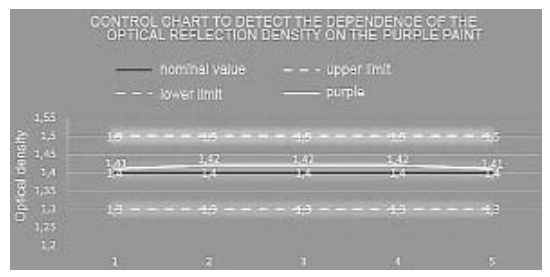

C drawn on the graph to understand how the process takes place. These horizontal lines are called the upper control limit (UCL), the center line $(\mathrm{CL})$ and the lower control limit (LCL). With these lines you can trace the following dependencies:

- if too many experimental points are above the UCL (below the LCL), the quality parameters do not meet the standards;

- if a number of experimental points are between $\mathrm{CL}$ and UCL (or CL and $\mathrm{LKL}$ ), it also means that the process requires intervention [9-11].

The research results are given in tab. 2. In fig. 1 we present the results of studies of changes in optical density for all four CMYK inks. For comparison, the optical density reference values are also plotted for the graph.

As can be seen, in almost all cases, changes in performance are within acceptable limits of \pm 0.1 . The largest deviation is observed

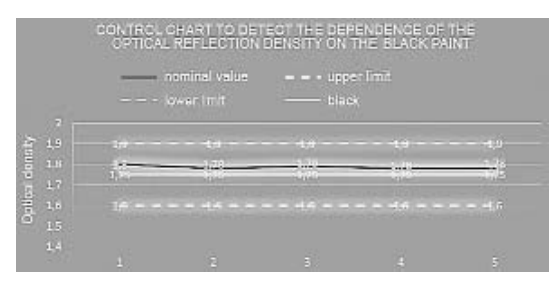

b

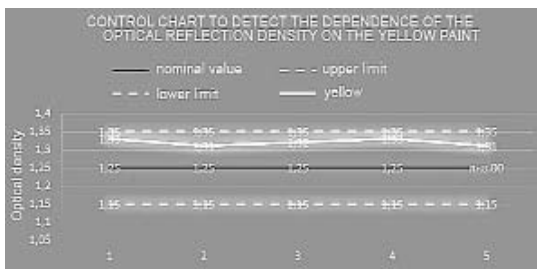

d

Fig. 1. Control maps of the dependence of optical density on time ( $\mathrm{a}$ - cyan ink, $\mathrm{b}$ - black ink, c - magenta ink, $\mathrm{d}$ - yellow ink) 
Table 2 in yellow ink. But, since it is the

The value of the optical density of circulation prints

(interval of $10 \mathrm{~min}$ )

\begin{tabular}{|c|c|}
\hline Ink color & The value of optical density \\
\hline Cyan & 1,$40 ; 1,45 ; 1,45 ; 1,43 ; 1,46$ \\
\hline Magenta & 1,$41 ; 1,42 ; 1,42 ; 1,42 ; 1,41$ \\
\hline Yellow & 1,$33 ; 1,31 ; 1,32 ; 1,33 ; 1,31$ \\
\hline Black & 1,$80 ; 1,78 ; 1,79 ; 1,78 ; 1,78$ \\
\hline
\end{tabular}

least noticeable to the human eye, it does not greatly affect the print quality. The most pronounced is the contour (black) ink. In this study, deviations in black ink are minimal.

To predict the print quality based on the structuring of the quality function, as a result of which we built the Quality House (fig. 2), we assessed the degree of density of paired interactions between consumer requirements and characteristics of printed material, which

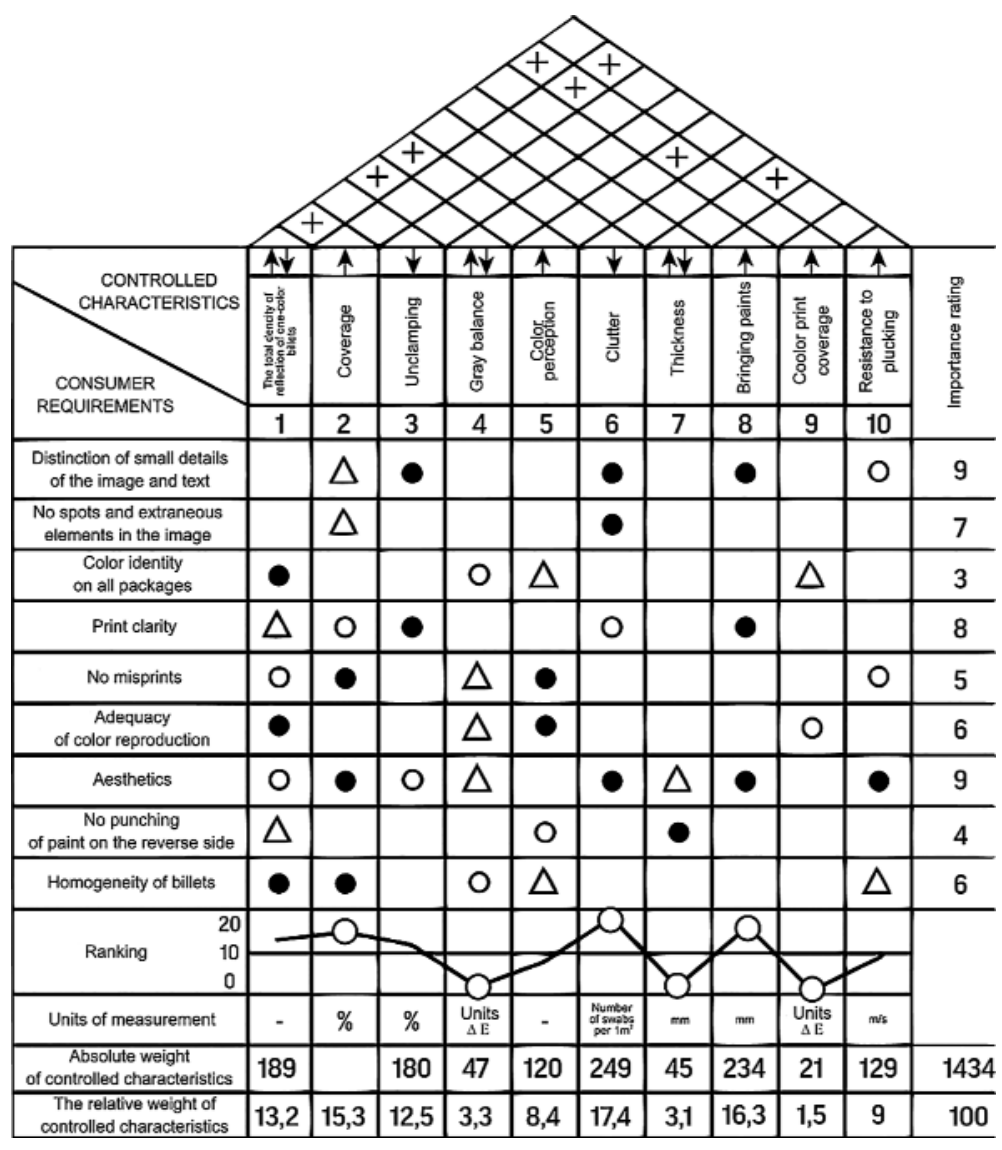

Fig. 2. Quality house for predicting print quality indicators (symbols are placed in the cells of the matrix degree of closeness:

- - strong, $\circ$ - medium, $\Delta$ - weak 
revealed the relationship between consumer requirements and controlled characteristics material; consumer requirements and print quality indicators [12].

\section{Conclusion}

Thus, we propose the possibility of applying the method of constructing a control chart to identify the causes of deviations of the optical density for the triad of inks in offset printing. According to the graphs of the dependence of the op- tical density on all four colors from time to time, it is seen that the largest deviation from the norm is observed for the yellow color. The most important requirements of cosumers are the distinction of small details of the image, text, clarity of printing, the absence of spots and foreign elements in the image, aesthetics.

The approaches developed in the work allow to determine the weakest place in the system of paper (cardboard) - printing ink and to assess the level of quality.

\section{References}

1. National standards of Ukraine (2009). DSTU ISO 9001:2009: Systemy upravlinnia yakistiu [Quality Management Systems]. Kyiv [in Ukrainian].

2. National standards of Ukraine (2005). DSTU ISO/TR 10017:2005: Nastanovy shchodo zastosuvannia statystychnykh metodiv [Guidelines for the Application of Statistical Methods]. Kyiv [in Ukrainian].

3. Demchuk, L. V. \& Baitsar, R. I. (2013). Statystychne upravlinnia yakistiu produktsii [Statistical Product Quality Management]. Journal of Materialy Mizhnarodnoi naukovo-praktychnoi konferentsii 'Problemy yakosti, standartyzatsii, sertyfikatsii ta metrolohichnoho zabezpechennia', 67-69 [in Ukrainian].

4. Borisova, A. S. \& Varepo, L. G. (2017). Prognozirovanie kachestva pechati na osnove strukturirovaniya funktsii kachestva [Predicting Print Quality Based on the Structuring of the Quality Function]. Journal of Izvestiya vysshikh uchebnykh zavedeniy. Problemy poligrafii i izdatel'skogo dela, 4, 27-35 [in Russian].

5. Varepo, L. G. \& Kolozova, O. A. \& Borisova, A. S. \& Golunov, A. V. (2007). Razrabotka matematicheskikh modeley kachestva poligraficheskikh ottiskov [Development of Mathematical Models of the Quality of Polygraphic Imprints]. Journal of Materialy II Miedzynarodowej naukowi-praktycznej konferencji 'Perspektywiczne opracowania nauki I techniki - 2007'. Tom 11. Techniczne nauki. Budownictwo i architektura. Matematyka. Fizyka. Nowoczesne informacyjne technologie. Przemysl: Nauka i studia, 56-59 [in Russian].

6. National standards of Ukraine (2008). DSTU ISO 12647-2:2008: Polihrafiia. Keruvannia protsesamy vyhotovliannia rastrovykh koloropodilenykh fotoform, probnykh i tyrazhnykh vidbytkiv. Chastyna 2. Protsesy ofsetnoho ploskoho drukuvannia [Printing Industry. Management of Processes of Production of Raster Color-Separated Films, Trial and Circulation Imprints. Part 2. Processes of Offset Flat Printing] (ISO 12647-2:2004, IDT + ISO 126472:2004/Amd. 1:2007, IDT). Kyiv [in Ukrainian].

7. Borisova, A. S. \& Varepo, L. G. (2011). K voprosu otsenki kachestva pechatnogo ottiska, nanesennogo na upakovku [On the Issue of Assessing the Quality of the Printed Imprint Applied to the Package]. Journal of Kachestvo, standartizatsiya, kontrol': teoriya i praktika, 13-15 [in Russian]. 
8. Varepo, L. G. \& Borisova, A. S. \& Golunov, A. V. (2010). Evaluation of surface microgeometry and quality provision of printed materials. Journal of Papers of the 42-th conference: international circle of educational institutes for graphic arts technology and management, 145-151 [in Russian].

9. Gudilin, D. (2007). Ofsetnaya pechat' na kartone: problemy standartizatsii [Offset Printing on Cardboard: Problems of Standardization]. Journal of Komp'yuArt, 6, 28-31 [in Russian].

10. Vernhes, P. \& Bloch, J.-F. \& Mercier, C. \& Blayo-Bernard Pineaux, A. (2008). Statistical analysis of paper surface microstructure: A multi-scale approach. Journal of Applied Surface Science, V. 254, Issue 22, 7431-7437 [in English].

11. Claypole, J. \& Williams, P. R. \& Deganello, D. (2018). Control of breakup of ink filaments in offset printing. Journal of IARIGAI 2018 proceedings: Advances in printing and media technology, Vol. 39, 207-211 [in English].

12. Deming, U. E. (2016). Vykhod iz krizisa. Novaya paradigma upravleniya lyud'mi, sistemami i protsessami [Way Out of the Crisis. A New Paradigm for Managing People, Systems and Processes]. Al'pina Pablisher, 417 p. [in Russian].

\section{Список використаної літератури}

1. ДСТУ ISO 9001:2009. Системи управління якістю.

2. ДСТУ ISO/TR 10017:2005. Настанови щодо застосування статистичних методів.

3. Демчук Л. В. Статистичне управління якістю продукції / Л. В. Демчук, Р. І. Байцар // Матеріали Міжнародної науково-практичної конференції «Проблеми якості, стандартизації, сертифікації та метрологічного забезпечення» (18-20 вересня 2013 р.). Херсон: Грінь Д. С., 2013. С. 67-69.

4. Борисова А. С. Прогнозирование качества печати на основе структурирования функции качества / А. С. Борисова, Л. Г. Варепо // Известия высших учебных заведений. Проблемы полиграфии и издательского дела. 2017. № 4. С. 27-35.

5. Варепо Л. Г. Разработка математических моделей качества полиграфических оттисков / Л. Г. Варепо, О. А. Колозова, А. С. Борисова, А. В. Голунов // Materialy II Miedzynarodowej naukowi-praktycznej konferencji «Perspektywiczne opracowania nauki I techniki - 2007». Tom 11. Techniczne nauki. Budownictwo i architektura. Matematyka. Fizyka. Nowoczesne informacyjne technologie. Przemysl: Nauka i studia. 2007. P. 56-59.

6. ДСТУ ISO 12647-2:2008 Поліграфія. Керування процесами виготовляння растрових кольороподілених фотоформ, пробних і тиражних відбитків. Частина 2. Процеси офсетного плоского друкування (ISO 12647 2:2004, IDT + ISO 12647-2:2004/Amd.1:2007, IDT).

7. Борисова А. С. К вопросу оценки качества печатного оттиска, нанесенного на упаковку / А. С. Борисова, Л. Г. Варепо // Качество, стандартизация, контроль: теория и практика: матер. 11-й Междунар. науч.-практ. конф., г. Ялта.-Киев: АТМ Украины, 2011. С. 13-15.

8. Varepo L. G. Evaluation of surface microgeometry and quality provision of printed materials / L. G. Varepo, A. S. Borisova, A. V. Golunov // Papers of the 42-th conference: international circle of educational institutes for graphic arts technology and management. M.: MSUPA, 2010. C. 145-151.

9. Гудилин Д. Офсетная печать на картоне: проблемы стандартизации // КомпьюАрт. 2007. № 6. С. 28-31. 
10. Piorre Vernhes. Statistical analysis of paper surface microstructure: A multi-scale approach / Piorre Vernhes, Jean-Francis Bloch, Christophe Mercier, Anne Blayo-Bernard Pineaux // Applied Surface Science, 15 September 2008. V. 254. Issue 22. P. 7431-7437.

11. Claypole J. Control of breakup of ink filaments in offset printing / J. Claypole, P. R. Williams, D. Deganello // IARIGAI 2018 proceedings: Advances in printing and media technology. Ljubljana, Slovenia, 2018. Vol. 39. P. 207-211.

12. Деминг У. Э. Выход из кризиса. Новая парадигма управления людьми, системами и процессами. Альпина Паблишер, 2016. 417 с.

Розглянуто шляхи контролю показників якості офсетного друку як основу стандартизації процесу. Запропоновано використання статистичних методів для контролю якості. Наведено приклади практичної реалізації запропонованих підходів для управління якістю друкарського процесу. Запропоновано можливість застосування методу побудови контрольної карти для виявлення причин відхилення показників оптичної густини для тріади фарб в офсетному друці.

Ключові слова: управління якістю; статистичні методи; офсетний друк; точність оцінки; контроль якості. 